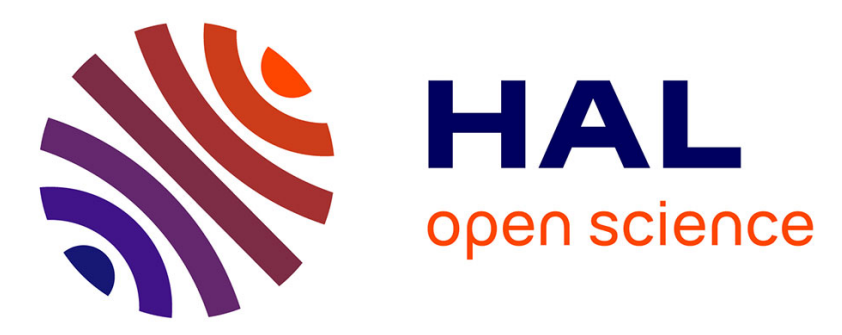

\title{
Effects of $17 \alpha$-ethynylestradiol on early-life development, sex differentiation and vitellogenin induction in mummichog (Fundulus heteroclitus)
}

Rebecca E.M. Peters, Simon C. Courtenay, Mark L. Hewitt, Deborah L. Maclatchy

\section{To cite this version:}

Rebecca E.M. Peters, Simon C. Courtenay, Mark L. Hewitt, Deborah L. Maclatchy. Effects of $17 \alpha$-ethynylestradiol on early-life development, sex differentiation and vitellogenin induction in mummichog (Fundulus heteroclitus). Marine Environmental Research, 2010, 69 (3), pp.178. 10.1016/j.marenvres.2009.10.002 . hal-00565110

\author{
HAL Id: hal-00565110 \\ https://hal.science/hal-00565110
}

Submitted on 11 Feb 2011

HAL is a multi-disciplinary open access archive for the deposit and dissemination of scientific research documents, whether they are published or not. The documents may come from teaching and research institutions in France or abroad, or from public or private research centers.
L'archive ouverte pluridisciplinaire HAL, est destinée au dépôt et à la diffusion de documents scientifiques de niveau recherche, publiés ou non, émanant des établissements d'enseignement et de recherche français ou étrangers, des laboratoires publics ou privés. 


\section{Accepted Manuscript}

Effects of $17 \alpha$-ethynylestradiol on early-life development, sex differentiation and vitellogenin induction in mummichog (Fundulus heteroclitus)

Rebecca E.M. Peters, Simon C. Courtenay, Mark L. Hewitt, Deborah L. MacLatchy

PII:

S0141-1136(09)00128-7

DOI:

10.1016/j.marenvres.2009.10.002

Reference:

MERE 3377

To appear in:

Marine Environmental Research

Received Date:

27 December 2007

Revised Date:

6 September 2009

Accepted Date:

7 October 2009

Please cite this article as: Peters, R.E.M., Courtenay, S.C., Hewitt, M.L., MacLatchy, D.L., Effects of $17 \alpha-$ ethynylestradiol on early-life development, sex differentiation and vitellogenin induction in mummichog (Fundulus heteroclitus), Marine Environmental Research (2009), doi: 10.1016/j.marenvres.2009.10.002

This is a PDF file of an unedited manuscript that has been accepted for publication. As a service to our customers we are providing this early version of the manuscript. The manuscript will undergo copyediting, typesetting, and review of the resulting proof before it is published in its final form. Please note that during the production process errors may be discovered which could affect the content, and all legal disclaimers that apply to the journal pertain. 
1 Effects of 17a-ethynylestradiol on early-life development, sex differentiation and

2 vitellogenin induction in mummichog (Fundulus heteroclitus)

4 Rebecca E. M. Peters ${ }^{1}$, Simon C. Courtenay ${ }^{2}$, Mark L. Hewitt ${ }^{3}$ and Deborah L.

5 MacLatchy $^{1^{*}}$

6

$7 \quad{ }^{1}$ Department of Biology and Canadian Rivers Institute

8 University of New Brunswick

9 Saint John, NB

10 Canada

11 E2L 4L5

12

$13{ }^{2}$ Fisheries and Oceans Canada at the Canadian Rivers Institute

14 Department of Biology, University of New Brunswick

15 Fredericton, NB

16 Canada

$17 \quad$ E3B 6E1

18

$19{ }^{3}$ National Water Research Institute

20 Environment Canada

21 Burlington, ON

22 Canada

$23 \quad$ L7R 4A6 
$25 *$ Author to whom correspondence should be addressed.

26 Email: dmaclatchy@wlu.ca

27

28 Present address:

29 Department of Biology and Canadian Rivers Institute

30 Wilfrid Laurier University

31 Waterloo, ON

32 Canada

$33 \quad$ N2L 3C5

34 Phone: 519 884-0710 ext 2221

35 Fax: $519746-2472$ 


\section{Abstract}

$37 \quad$ Fertilized mummichog eggs retrieved from 17 1 -ethynylestradiol $\left(\mathrm{EE}_{2}\right)$ exposed

38 adult fish were raised in concentrations of $\mathrm{EE}_{2}$ ranging from 0 to $100 \mathrm{ng} / \mathrm{L}\left(100 \mathrm{ng} / \mathrm{L} \mathrm{EE}_{2}\right.$

39 estimated to have actual average exposure concentrations of $30 \%$ of nominal; 0.1 to

$40 \quad 10 \mathrm{ng} / \mathrm{L}$ were below detect throughout 24 -h exposure period) for 61 weeks post-hatch.

41 Eggs exposed at 100ng/L hatched sooner, the larvae were longer, and survival of juvenile

42 fish from hatch to study termination was greater than all other treatments, though fewer

43 hatched at this treatment. Sex ratios were skewed ( $>80 \%$ female phenotype) at 100ng/L

$44 \mathrm{EE}_{2}$, and some gonadal male fish displayed female secondary sex characteristics.

45 Condition factor, gonadosomatic index (GSI), and liver somatic index (LSI) were found

46 to decrease in both sexes between 52 and 61 weeks post-hatch. Female fish had

47 increased hepatic vitellogenin (VTG) at 52 weeks post-hatch. When exposed to 1, 10 and

$48100 \mathrm{ng} / \mathrm{L} \mathrm{EE}_{2}$, female fish had a higher proportion of vitellogenic follicles in the ovarian

49 tissue. Males exposed at 100ng/L may have had disruption at some endpoints (GSI,

50 VTG) that is masked due to reduced sample size compared to other treatments. Fish

51 exposed to concentrations of $\mathrm{EE}_{2}$ at or below $10 \mathrm{ng} / \mathrm{L}$ showed inconsistent effects on

52 development and reproductive potential. This study indicates the potential for

53 population-level effects at the high range of environmental $\mathrm{EE}_{2}$ at concentrations

54 equivalent to those at which consistent effects in fecundity in the adult mummichog

55 reproductive test have been measured. This work demonstrates that chronic $\mathrm{EE}_{2}$

56 exposure causes developmental effects at concentrations similar to those which cause

57 effects in the shorter-term adult mummichog reproductive test. Effects are at higher

58 concentrations than have been noted for freshwater model species. Whether this is 
59 because of species sensitivity or due to differences between freshwater and saltwater

60 availability of $\mathrm{EE}_{2}$ or its uptake requires further study. 
61 Key Words

62 Ethynylestradiol, Fundulus heteroclitus, vitellogenin, sex differentiation, development,

63 lifecycle, bioassay, endocrine disruption 


\section{Introduction}

65 Endocrine disrupting substances (EDSs) are exogenous substances or mixtures

66 that alter function of the endocrine system and consequently cause adverse effects in

67 individuals or their progeny (OECD, 1999). Effects of pulp mill effluents in Canada

68 (Hewitt et al. 2008) and sewage in Britain (Jobling and Tyler 2003) provide some of the

69 best examples of endocrine disruption in wild fish. Recently, in a whole-lake experiment,

70 chronic exposure of fathead minnow to low concentrations (5-6ng/L) of $17 \alpha-$

71 ethynylestradiol $\left(\mathrm{EE}_{2}\right)$ caused feminization and intersex in males, induced vitellogenesis,

72 altered oogenesis in females, and caused a near collapse of the population (Kidd et al.

73 2007). EDSs may interfere with any part of endocrine control, including production,

74 release, transport, metabolism, receptor binding, action or elimination. The sum total of

75 these effects can be measured in fish laboratory bioassays designed to assess

76 reproduction, development and growth (Patyna et al., 1999; Zillioux et al., 2001; Parrott

77 and Wood, 2002; Seki et al., 2004). Chronic exposure to xenobiotics can induce changes

78 to organisms not noted by shorter-term exposures (Parrott and Blunt, 2005), including

79 factors that may be manifested at the population level, such as lower recruitment (Ankley

80 et al., 2001).

81 Lifecycle bioassays or multigenerational bioassays have been developed in

82 freshwater fish species, including the fathead minnow, Pimephales promelas (Ankley et

83 al., 2001; Länge et al., 2001), Japanese medaka, Oryzias laripes (Seki et al., 2003) and

84 zebrafish, Danio rerio (Olsson et al., 1999). Partial lifecycle and short-term bioassays

85 have been developed for estuarine and marine species; examples include sheepshead

86 minnow, Cyprinodon variegates (Folmar et al., 2000; Zillioux et al., 2001; Hemmer et 
87 al., 2008) and mummichog, Fundulus heteroclitus (MacLatchy et al., 2003; Boudreau et

88 al., 2004; Peters et al. 2007; Bosker et al., 2009). Effects of EDSs on species living in

89 salt water may be quite different than those in fresh water because of differences in

90 biological availability of the contaminants based on physical water chemistry and fish

91 physiology (e.g., in contaminant uptake). Therefore, studies focused on the effects of

92 EDSs on estuarine species are warranted, especially given the extent of coastal activity by

93 humans and the importance of estuaries as spawning and nursery grounds (Oberdörster

94 and Cheek, 2001).

95 Mummichog are the numerically dominant fish species in salt marshes along the

96 east coast of Canada and the United States (Armstrong and Child, 1965), and have

97 demonstrated sensitivity to EDSs in laboratory (MacLatchy et al., 2003; Peters et al.,

98 2007), artificial stream (Dubé et al., 2002), and field (Leblanc et al., 1997) assessments.

99 The mummichog is a good candidate for lifecycle bioassay development due to its size,

100 ease of husbandry and ability to manipulate its reproductive cycles. Mummichog are

101 relatively sedentary, exhibiting small home ranges in the wild (Skinner et al. 2005) and

102 they are potentially exposed to environmental EDSs throughout their life cycle.

$103 \quad \mathrm{EE}_{2}$ has been chosen as a model EDS for developing bioassays due to its

104 environmental relevance as well as its confirmed effects on the reproductive endocrine

105 system via estrogen receptor-mediated pathways (OECD, 1999; Ankley et al., 2001;

106 Metcalfe et al., 2001; MacLatchy et al., 2003). $\mathrm{EE}_{2}$ is one component of sewage effluent

107 associated with increased incidence of intersex in male fish exposed downstream of

108 sewage treatment plants (STPs) (Jobling and Tyler, 2003). It is a synthetic

109 pharmaceutical (birth control pill and hormone replacement therapy) that is not broken 
110 down in sewage treatment; concentrations of $\mathrm{EE}_{2}$ present in Canadian STPs are usually

111 between 1-10ng/L EE 2 , although levels have been documented as high as $42 \mathrm{ng} / \mathrm{L}$

112 (Desbrow et al., 1998; Ternes et al., 1999). In earlier short-term (7- or 15-day) exposure

113 studies using $\mathrm{EE}_{2}$, adult mummichog displayed endocrine impacts at low,

114 environmentally-relevant concentrations, as well as similar responses at higher

115 pharmaceutical concentrations (MacLatchy et al., 2003). In longer-term (21-or 28-day)

$116 \mathrm{EE}_{2}$ exposures, reproductive cycling was shifted in females, sex steroid production and

117 circulating levels were altered and at environmentally-relevant (approximately $20 \%$ of

118 nominal 100ng/L exposures), fecundity and fertility were reduced (Peters et al., 2007).

119 The objective of this study was to determine the impact of chronic $\mathrm{EE}_{2}$ exposure

120 on offspring development. Embryos derived from mummichog parents exposed during

121 pre-spawning and spawning phases to $\mathrm{EE}_{2}$ were continuously exposed to $\mathrm{EE}_{2}$ for 15

122 months, through their development to pre-spawning juveniles/adults. Embryonic/larval

123 endpoints (time to hatch, hatch success, length at hatch), larval/juvenile endpoints

124 (growth, survival, vertebral abnormalities) and yearling endpoints (liver vitellogenin,

125 gonad and liversomatic indices, condition factor, sex ratios) were evaluated for

126 anomalies. This study, in conjunction with our previous studies (MacLatchy et al., 2003,

127 Boudreau et al., 2004; MacLatchy et al., 2005; Boudreau et al., 2005; Sharpe et al., 2004;

128 Peters et al., 2007) furthers our ability to understand the effects of EDSs on various life

129 stages of mummichog. This study demonstrates that developmental stages of

130 mummichog are sensitive to $\mathrm{EE}_{2}$ at exposure levels similar to those that interfere with

131 reproduction in adult mummichog (Peters et al. 2007), and that the concentrations at 
132 which effects occur are higher than those noted in freshwater model species (Länge et al.

133 2001; Andersen et al., 2003).

134

135 Materials and Methods

136 Chemicals

137 The $17 \alpha$-ethynylestradiol $\left(\mathrm{EE}_{2} ; 98 \%\right.$ purity) was purchased from Sigma-Aldrich

138 Canada (Oakville, ON, Canada). $\mathrm{EE}_{2}$ was stored at $-20^{\circ} \mathrm{C}$ in $100 \%$ ethanol (Les Alcools

139 de Commerce, Boucherville, QC, Canada) at stock concentrations of $3 \mathrm{ng} / \mathrm{mL}, 30 \mathrm{ng} / \mathrm{mL}$,

$140300 \mathrm{ng} / \mathrm{mL}$ and $3000 \mathrm{ng} / \mathrm{mL} \mathrm{EE}_{2}$ for adult exposures and $10 \mathrm{ng} / \mathrm{mL}, 100 \mathrm{ng} / \mathrm{mL}, 1000 \mathrm{ng} / \mathrm{mL}$

141 and $10000 \mathrm{ng} / \mathrm{mL} \mathrm{EE}_{2}$ for larval and juvenile exposures. Unless otherwise indicated,

142 chemicals and reagents were purchased from Sigma-Aldrich and laboratory supplies from

143 Fisher Scientific (Nepean, ON, Canada).

144

145 Experimental Conditions

146 Collection and breeding protocols for adult mummichog used in this study have

147 previously been described (Peters et al., 2007). Offspring were maintained at the same

148 exposure conditions as their parental groups at $0,0.1,1,10$, or $100 \mathrm{ng} / \mathrm{L} \mathrm{EE}_{2}$, in static

149 conditions with daily water changes and treatment renewal for the 61-week study period.

150 As deyeloping embryos, larvae, fry and juveniles grew, photoperiod was adjusted to

151 simulate seasonal day length: 16:8 h light:dark at initiation (July); 14:10 h light:dark at

152 week 14 (October); 12:12; light:dark at week 20 (November); 14:10 light:dark at week 32

153 (February); 15:9 light:dark at week 40 (April); and 16:8 light:dark from week 46 (May)

154 to termination of the experiment. Temperature was held at room temperature, which 
155 decreased slightly from $18-21^{\circ} \mathrm{C}$ in the summer (weeks $1-20$ ) to $16-18^{\circ} \mathrm{C}$ for the winter

156 (weeks $21-40$ ), returning to $18-21^{\circ} \mathrm{C}$ for the remainder of the study.

157 Larvae were fed live, newly hatched Artemia sp. nauplii (Bohai Bay Salt Ponds

158 Artemia Cysts, Aquatic Ecosystems, Apopka, FL, USA) enriched with Roti-rich ${ }^{\mathrm{TM}}$

159 (Aquatic Ecosystems) twice daily (1 mL of concentrated Artemia per L of water) and Fry

160 Food (Rolf C. Hagen, Montreal, QC, Canada) to satiation once daily for 14 weeks.

161 Beginning at 8 weeks, freeze-dried Red Grubs (Rolf C. Hagen) were used to supplement

162 the Fry Food diet as the juveniles were weaned from the Artemia. Flaked Staple Food

163 (Rolf C. Hagen) was introduced as the primary feed at 22 weeks, fed 2-3 times daily,

164 supplemented by Red Grubs or Cichlid Food (Rolf C. Hagen) once daily.

Exposures

167 Naturally-spawned, fertilized mummichog eggs were collected from adults

168 exposed to nominal exposure concentrations of $0,0.1,1,10$, or $100 \mathrm{ng} / \mathrm{L} \mathrm{EE}_{2}$ for 21 and

169 28-days as previously reported (Peters et al., 2007). The fertilized eggs were transferred

170 to glass Petri dishes at an initial density of 30 eggs per dish and held in $50 \mathrm{~mL}$ of $20 \%$

171 salinity $\mathrm{EE}_{2}$-treated water. Each dish was examined daily at $4 \mathrm{X}$ magnification, and dead

172 embryos and hatched larvae were removed. The water was then removed from each dish

173 and replaced with $50 \mathrm{~mL}$ of water treated with the appropriate amount of $\mathrm{EE}_{2}$. Time to

174 hatch, survival to hatch and length at hatch were monitored over the hatching period.

175 Upon hatch, larvae were maintained in $50 \mathrm{~mL}$ beakers containing the appropriate

$176 \mathrm{EE}_{2}$ concentrations and held at a maximum density of 10 larvae per beaker. Once the

177 yolk sac was absorbed (1-3 days) and swimming began, the larvae were randomly 
178 allocated to one of four aerated, static 37-L aquaria per treatment. Daily water renewals

179 were done by completely replacing the water and adding new treatment solution in each

180 tank after removing fish with a dip net and placing them in a temporary holding

181 aquarium; fish were returned to their original treatment tanks following the water change.

182 Upon initiation of the growout phase, each aquarium contained $5 \mathrm{~L}$ of $\mathrm{EE}_{2}$-treated $20 \%$

183 saline water (dissolved oxygen $>80 \%$ saturation). At five weeks, the volume of water in

184 each aquarium was increased to $10 \mathrm{~L}$ to accommodate growing larvae. Beginning at 10

185 weeks, volumes of water were adjusted separately for each tank to minimize the effect of

186 density differences among the tanks due to differential survival. Water volume was set to

$1871 \mathrm{~L}$ per $1 \mathrm{~g}$ total wet weight of the fish in the aquarium and was adjusted every $3-4$ weeks

188 for the remainder of the experiment. Each tank was replaced $100 \%$ daily throughout the

189 exposure period. Due to a dosing error in week 14, replicate tanks for 0ng/L and 100ng/L

$190 \mathrm{EE}_{2}$ were reduced to three tanks for subsequent endpoints.

191 Growth was determined weekly for the initial seven-week period, and then

192 approximately every three weeks for the remainder of the experiment by collecting total

193 length measurements (to the nearest $\mathrm{mm}$ ) from 25 fish removed, measured and returned

194 to each aquarium. Survival was determined from the number of fish in each tank on each

195 measurement day, and calculated as the proportion of the original number of fish in the

196 tank. Vertebral abnormalities were assessed at weeks 15, 48 and 61 and ranged from

197 mild (one or two slight bends in the spine) to severe (one or more bends in the spine that

198 dramatically altered body shape and/or affected swimming ability) and included scoliosis

199 (lateral curvature) and lordosis (dorsoventral curvature) (Boudreau et al., 2004). 
At week 48 (May 2004), all fish were assessed for weight (to $0.001 \mathrm{~g}$ ), standard

201 and total length (mm), vertebral abnormalities and external sex. Sex was determined

202 based upon colouration and secondary sex characteristics including yellow bellies, dark

203 dorsal fin spot, silver vertical stripes, white or yellow spots in males, and brown or green

204 backs and pale bellies in females. At week 52 (22 June 2004), less than a week following

205 the full moon, 20 fish were randomly sampled from each aquarium except one $1 \mathrm{ng} / \mathrm{L}$

206 aquarium and one $100 \mathrm{ng} / \mathrm{L}$ aquarium where 0 and 15 fish were selected respectively, due

207 to low numbers of fish in these tanks. These fish were anaesthetized (buffered $0.05 \%$

208 tricaine methane sulfonate; Syndel Laboratories, Vancouver, BC, Canada), assessed for

209 weight (to $0.001 \mathrm{~g}$ ), standard and total length $(\mathrm{mm})$, vertebral abnormalities and sex based

210 upon secondary characteristics and gonadal assessment at $4 \mathrm{X}$ magnification.

211 Vitellogenin (VTG) in the liver was assessed at week 52 using an ELISA

212 modified from MacLatchy et al. (2003). Liver tissue was dissected out, weighed, frozen

213 on dry ice, and then stored at $-80^{\circ} \mathrm{C}$. For each mg of liver tissue, $1 \mu \mathrm{L}$ of aprotinin

$214(1 \mathrm{KIU} / \mu \mathrm{L})$ was added to the microfuge tube. Tissue was thawed and homogenized with a

215 Kontes Pellet Pestle hand-held homogenizer. A small amount of the slurry $(5 \mu \mathrm{L})$ was

216 diluted 100X with Tris buffered saline containing Tween and bovine serum albumin and

217 assayed as per MacLatchy et al. (2003). Prior to analysis, the method was tested by

218 spiking liver slurry samples with a known concentration of VTG. Recovery of the spiked

219 amount of VTG [recovered VTG $=0.549+1.071 *\left(\right.$ spiked VTG); $\left.{ }^{2}=0.774 ; \mathrm{p}<0.001\right]$

220 was $88 \%$. Interassay variability was $7 \%$ and intra-assay variability was $6 \%$.

221 Gonadal tissue collected at week 52 was fixed in $10 \%$ buffered formalin and

222 stored in $70 \%$ ethanol. Tissues were embedded in paraplast and sectioned at $7 \mu \mathrm{m}$ using 
223 a rotary microtome. Tissue sections were stained with Mallory stain and examined with a

224 light microscope at 10X magnification for female tissue and 40X magnification for male

225 tissue. For each fish that had sufficient tissue, six fields of view (at different depths into

226 the gonad) were assessed for intersex and to determine developmental stage at week 52.

227 Using the terminology for developmental stage of Blazer (2002), the number of

228 previtellogenic and vitellogenic follicles were counted in females and the developmental

229 stage(s) of the testes were determined for each field of view.

230 At week 61 (August 2004), four days prior to the full moon, all remaining fish

231 were sampled and assessed for weight $(0.001 \mathrm{~g})$, standard and total length $(\mathrm{mm})$, vertebral

232 abnormalities and sex based upon secondary characteristics and gonadal assessment at

$2334 \mathrm{X}$ magnification. At 52 weeks, the fish were not reproductive and by 61 weeks were

234 beginning to regress; therefore, a breeding trial could not be carried out and the

235 experiment was terminated.

$237 \quad E_{2}$ Analysis

238 Analysis of the concentration of $\mathrm{EE}_{2}$ in the water was unavailable for this study

239 due to insufficient water volumes collected for analysis. Therefore, a subsequent two-

240 week exposure of adult mummichog (with equivalent volume of water and mass of fish

241 as per juvenile exposures) was conducted in duplicate aquaria at nominal concentrations

242 of 0 and $100 \mathrm{ng} / \mathrm{L} \mathrm{EE}_{2}$. Volumes of water extracted and analyzed were 1L. $\mathrm{EE}_{2}$ levels

243 were extracted and analyzed as previously described (Peters et al., 2007) with additional

244 method standardization to ensure $\mathrm{EE}_{2}$ recovery in salt water. The water concentrations

245 for the $100 \mathrm{ng} / \mathrm{L} \mathrm{EE}_{2}$ treatment aquaria were highest at the point of delivery $(74.7 \mathrm{ng} / \mathrm{L})$ 
246 and decreased with time to $66.8 \mathrm{ng} / \mathrm{L}$ at $1 \mathrm{~h}$ and $30.7 \mathrm{ng} / \mathrm{L}$ at $6 \mathrm{~h}$; at 12 and $24 \mathrm{~h} \mathrm{EE_{2 }}$ levels

247 were undetectable (detection limit at 10ng/L). Because of the inability to determine

248 exposure concentrations at exposures $<10 \mathrm{ng} / \mathrm{L}$ nominal, all exposure concentrations are

249 given as nominal values.

251 Statistics

252 Statistical analyses were conducted using SigmaStat 3.0 (SPSS, Chicago, IL,

253 USA) or Systat 9.0 (Systat Software Inc., Richmond, CA, USA). Significant differences

$254(\mathrm{p}<0.05)$ among the data were assessed separately for each sex when it was possible to

255 determine gonadal sex. Prior to parametric analysis, assumptions of normality and

256 variance homogeneity were tested on morphological data using normal probability plots

257 and Levene's test. Where the data failed to meet the assumptions, they were $\log _{10}$

258 transformed and the assumptions retested. If the data still failed to meet the assumptions,

259 an equivalent non-parametric test was used. Measures of time to hatch, hatch success

260 rate, and length at hatch were assessed using single factor ANOVA, using Petri dishes as

261 the replication units. Mortality, vertebral abnormalities and liver VTG were assessed

262 using single factor ANOVA, with aquarium as the unit of replication. Vitellogenin data

263 were examined for outliers using Dixon's test prior to analysis. Analyses of weight and

264 length were performed using a nested analysis of variance (ANOVA) followed by

265 Tukey's or Dunn's tests, with aquarium as the factor nested within treatment group.

266 Kruskal-Wallis was used when the data failed to meet parametric assumptions.

267 Differences in gonadal and liver weights relative to body weights (gonadosomatic index;

268 GSI; [gonad wt/body wt]·100; and liversomatic index; LSI; [liver wt/body wt]·100), body 
269 weight to standard length (condition factor; CF; [body wt/standard length $\left.{ }^{3}\right] \cdot 100$ ), and

270 total length over time (growth) were determined using analysis of covariance

271 (ANCOVA). The interaction term significance was set at $\mathrm{p}=0.1$ (Environment Canada,

272 2005). Differences in morphological variables between sampling dates were assessed

273 using A. Student's t-test. Sex ratios and gonadal development ratios were assessed using

274 a chi-square analysis for proportions, with expected proportions set at 50:50, followed by

275 an angular transformation and Tukey-type multiple comparison (Zar, 1999). Values are

276 reported as means \pm standard error $(\mathrm{SE})$.

278 Results

279 Eggs exposed to $10 \mathrm{ng} / \mathrm{L}$ and100ng/L EE 2 hatched sooner than eggs exposed to

280 0ng/L EE $E_{2}(p=0.018$; Fig. 1). Eggs exposed to 100ng/L EE 2 had significantly lower hatch

281 success than those in $0,0.1$, and $1 \mathrm{ng} / \mathrm{L}(\mathrm{p}<0.001$; Fig. 1). Larvae hatched at 1 and

$282100 \mathrm{ng} / \mathrm{L} \mathrm{EE} 2$ were significantly longer than those at $0,0.1$ and $10 \mathrm{ng} / \mathrm{L}(\mathrm{p}<0.001 ;$ Fig. 1$)$.

283 Weight at length (condition factor) for both sexes decreased between week 48

284 (data not shown) and week 61 in all treatment groups. There were no differences in

285 weight at length in male or female fish between $0 \mathrm{ng} / \mathrm{L}$ and any other treatment at weeks

28648,52 (data not shown) or 61 (Table 1).

287 Post-hatch survival was found to be significantly higher for 100ng/L exposed fish 288 than any other treatment $(\mathrm{p}<0.001$; Fig. 2$)$. At week 15 the proportion of fish exhibiting

289 vertebral abnormalities at $0.1,10$, and $100 \mathrm{ng} / \mathrm{L}$ were significantly lower than at 0 and

$2901 \mathrm{ng} / \mathrm{L}(\mathrm{p}=0.021 ;$ Fig.3). These differences among treatments were not retained at 48 nor

29161 weeks (data not shown). 
Male fish exposed to $100 \mathrm{ng} / \mathrm{L} \mathrm{EE}_{2}$ had significantly lower GSI at 52 weeks $293\left(\mathrm{p}=0.016 ; 1.42 \pm 0.15\right.$ at $0 \mathrm{ng} / \mathrm{L}$ vs $0.60 \pm 0.23 \mathrm{ng} / \mathrm{L}$ at $\left.100 \mathrm{ng} / \mathrm{L} \mathrm{EE}_{2}\right)$ but not at 61 weeks

294 post-hatch (Table 1) and between week 52 and week 61, male GSI decreased in all

295 treatments except $100 \mathrm{ng} / \mathrm{L} \mathrm{EE}_{2}$ (data not shown). No differences were found in male LSI

296 among treatments at weeks 48, 52 (data not shown) or 61 (Table 1). There was no

297 difference in female GSI among treatments at 52 weeks ( $\mathrm{p}=0.641$; range of $2.55 \pm 0.14$ at

$2980.1 \mathrm{ng} / \mathrm{L}$ to $4.81 \pm 0.99$ at $100 \mathrm{ng} / \mathrm{L}$ ) or 61 weeks (Table 1 ) though female GSI decreased

299 between week 52 and week 61 in fish exposed to $0,0.1$, and $1 \mathrm{ng} / \mathrm{LEE}_{2}$. No differences

300 in female LSI were found among fish exposed at $0 \mathrm{ng} / \mathrm{L}$ and any other treatment (weeks

30148 and 52, data not shown; week 61, Table 1).

302 At 52 weeks post-hatch, there was no difference among treatments in liver VTG

303 in males ( $\mathrm{p}=0.732$; data not shown). There was an increase in liver VTG in females

304 exposed to $100 \mathrm{ng} / \mathrm{L} \mathrm{EE}_{2}$ compared to all other treatments ( $\mathrm{p}<0.001$; approximately 10 -

305 fold increase from $1500-2500 \mu \mathrm{g} / \mathrm{mg}$ VTG at $0-10 \mathrm{ng} / \mathrm{L} \mathrm{EE} 2$ to 14,000 to $17,000 \mu \mathrm{g} / \mathrm{mg}$

306 VTG at 100ng/L EE 2 .

307 At 52 weeks post-hatch, sex ratios based on secondary sexual characteristics were

308 significantly different at $100 \mathrm{ng} / \mathrm{L}$, with females accounting for greater than $90 \%$ of the

309 fish at this concentration $(\mathrm{p}<0.001$; Table 2$)$. Secondary sex characteristics differed in a

310 similar fashion at the highest exposure at 48 and 61-weeks post-hatch. Visual

311 examination of the gonads at 52 weeks post-hatch found sex ratios to be significantly

312 different at $100 \mathrm{ng} / \mathrm{L} \mathrm{EE}_{2}$; the proportion of females was $86.8 \%$ ( $<<0.001$; Table 2).

313 Histological analysis of the gonads found sex ratios to be significantly different at

$314100 \mathrm{ng} / \mathrm{L} \mathrm{EE}_{2}$; the proportion of females was $86.1 \%(\mathrm{p}<0.001$; Table 2$)$. There were 
315 significantly more vitellogenic oocytes in female fish exposed to 1,10 and $100 \mathrm{ng} / \mathrm{L} \mathrm{EE}_{2}$

316 when compared to the group exposed to $0 \mathrm{ng} / \mathrm{L} \mathrm{EE}_{2}(\mathrm{p}<0.001$; Table 3$)$. There was only a

317 single case of intersex, where a male fish (tissue was primarily prespermatogenic)

318 exposed to $0.1 \mathrm{ng} / \mathrm{L} \mathrm{EE}_{2}$ had three previtellogenic oocytes within the tissue. The

319 proportion of male gonadal tissue at each maturation stage did not differ among

320 treatments $(\mathrm{p}>0.05$; Table 3$)$.

321

322 Discussion

323 Previous studies in our laboratories (MacLatchy et al., 2003; Boudreau et al.,

324 2004; Peters et al., 2007) examined the effects of $\mathrm{EE}_{2}$ exposure on adult and larval

325 mummichog. This present work addresses questions that arose from these studies,

326 including whether a standardized, multigenerational protocol could be developed for EDS

327 studies to correlate physiological effects with population and/or reproductive impacts in

328 mummichog as has been suggested for other fish species (Patyna et al., 1999; Ankley et

329 al., 2001). The eggs used in this study were spawned and fertilized in a short-term

330 reproductive bioassay in which adult mummichog were exposed to concentrations of $\mathrm{EE}_{2}$

331 ranging from 0 to $100 \mathrm{ng} / \mathrm{L}$ (nominal) for 21 and 28 days (Peters et al., 2007). The rearing

332 of these eggs to sexual maturity provides a more complete understanding of the total

333 impact of chronic and lifecycle $\mathrm{EE}_{2}$ exposure in an estuarine species. Long-term

334 exposure to the highest concentration (100ng/L nominal; approximately $30 \%$ of exposure

335 concentration) resulted in a higher proportion of fish with female secondary sex

336 characteristics and gonads. As well, female livers contained higher VTG levels at this

337 concentration. These $\mathrm{EE}_{2}$-induced changes occurred only at the highest concentrations 
338 and parallel the physiological and reproductive effects observed in the parents of these

339 offspring (decreased circulating steroids, increased VTG, decreased egg production and

340 decreased fecundity/fertility; Peters et al., 2007) during shorter exposure periods.

341 In the progeny generation, hatching success was reduced when parents and eggs

342 were exposed to $100 \mathrm{ng} / \mathrm{L} \mathrm{EE}_{2}$. Decreases in both spawning output and fertilization

343 success during adult exposure to $100 \mathrm{ng} / \mathrm{L} \mathrm{EE}_{2}$ have been demonstrated in mummichog in

344 our laboratory (Peters et al., 2007). The effects on progeny may be a threshold effect, as

345 there is no indication of similar difficulties in spawning, fertilization or hatching at $\mathrm{EE}_{2}$

346 levels $<10 \mathrm{ng} / \mathrm{L}$ (this study; Peters et al., 2007). However, a concentration-dependent

347 response may exist between exposure concentrations of 10 and $100 \mathrm{ng} / \mathrm{L} \mathrm{EE}_{2}$.

348 Sheepshead minnow exposed to $\mathrm{EE}_{2}$ showed reduced egg production at 20 and 200ng/L

349 and reduced hatching at 200ng/L (Zillioux et al., 2001). Hatching success decreased in a

350 dose-dependent manner in larval mummichog exposed to estradiol ( $\left.\mathrm{E}_{2}\right)$ (Urushitani et al.,

3512002 ) and estrogenic alkylphenols caused complete larval mortality at concentrations

$352 \geq 10 \mu \mathrm{M}$ and hatching success was $<10 \%$ below this concentration (Kelly and Di Giulio,

353 2000).

$354 \quad \mathrm{AsE}_{2}$ concentrations increased, there was a decrease in the egg incubation

355 period prior to hatch. Shortened time to hatch has been documented in zebrafish exposed

356 to the weakly estrogenic pesticide methoxychlor (Versonnen et al., 2004) and brown trout

357 (Salmo trutta) exposed to wood-sterols (Lehtinen, et al., 1999). Larvae that emerged in

358 the present study were significantly longer when exposed to 1 and $100 \mathrm{ng} / \mathrm{L} \mathrm{EE}_{2}$.

359 Exposure to $\mathrm{EE}_{2}$ prior to spawning and fertilization may affect the developing oocyte

360 before the development of the protective chorion and associated membranes of the egg 
361 that prevent exogenous compounds from reaching the developing embryo (Anadu et al.,

362 1999).

363 Survival from hatch to the conclusion of the study was found to be significantly

364 higher for $100 \mathrm{ng} / \mathrm{L} \mathrm{EE}_{2}$-exposed fish than any other treatment. Fathead minnow exposed

365 to $\mathrm{EE}_{2}$ from fertilization showed no differences in survival among treatments (Länge et

366 al., 2001). Mummichog exposed for 60 days and reared in clean water showed increased

367 survival at $10 \mathrm{ng} / \mathrm{L}$, no change in survival at $1000 \mathrm{ng} / \mathrm{L}$ and decreased survival at

$36810,000 \mathrm{ng} / \mathrm{L} \mathrm{EE}_{2}$ (Boudreau et al., 2004). After 10 weeks of the growout period, volumes

369 in all the aquaria were adjusted to compensate for fish numbers in an attempt to eliminate

370 potential density-dependent effects. Boudreau et al. (2004) suggested that decreasing

371 density by increasing volume of water and/or decreasing number of fish reduced

372 mortalities in mummichog. It is also possible that the decreased mortality post-hatch in

373 the $100 \mathrm{ng} / \mathrm{L}$ treatment was the result of increased embryonic mortality, which weeded-

374 out weaker fish.

375 There were no differences in male or female condition (length at weight)

376 throughout the study and differences in vertebral abnormalities observed among

377 treatments at week 15 were not present at week 48 or 61 . The proportion of $0 \mathrm{ng} / \mathrm{L}$ fish

378 exhibiting vertebral abnormalities decreased over time, and may be attributable to the

379 mortality of these fish. The growth of soft-tissue that hides underlying abnormalities has

380 previously been suggested as a mechanism that decreases observable deformities

381 (Boudreau et al., 2004). Whether any of the endpoints measured in relation to time to

382 hatch, size at hatch, juvenile growth, abnormalities, etc., are significant from a

383 population/biological standpoint requires more study, especially in a field situation. It 
384 has long been known that size at hatch, growing season length, and food availability all

385 significantly affect long-term survival in wild fish populations (Andersen, 1988;

386 Cargnelli and Gross, 1996) making any size deficiency an issue in the wild.

$387 \quad$ VTG production in the liver naturally occurs in female fish once a threshold level

388 of $\mathrm{E}_{2}$ is reached in the hepatic estrogen receptors (Denslow et al., 1999). VTG is a

389 sensitive biomarker of estrogen exposure; exogenous estrogen induces VTG synthesis in

390 female and male and/or juvenile fish (Denslow et al., 1999) in both freshwater (Panter et

391 al., 2002) and saltwater (MacLatchy et al., 2003) species. VTG induction as an indicator

392 of decreased reproductive potential has recently been assessed in fathead minnow (Miller

393 et al., 2007) and high levels can cause kidney problems in físh (Folmar et al., 2001).

394 There was no difference in liver VTG in male fish at week 52. However, the mean VTG

395 for males exposed to $100 \mathrm{ng} / \mathrm{L} \mathrm{EE}_{2}$ was more than twice the mean of male fish exposed to

$3960 \mathrm{ng} / \mathrm{L} \mathrm{EE}_{2}$. There were only five fish identified as male in the $100 \mathrm{ng} / \mathrm{L} \mathrm{EE}_{2}$ treatments,

397 compared to 23-39 fish in each of the other treatments. The small sample size for male

398 fish at this treatment level may be masking any effect on VTG. Alternatively, during a

399 long exposure, feedback and regulatory physiological mechanisms may allow the fish to

400 achieve homeostasis and prevent a VTG response (Länge et al., 2001). Females exposed

401 to $100 \mathrm{ng} / \mathrm{L} \mathrm{EE}_{2}$ had increased liver vitellogenin compared to all other treatments.

402 Medaka exposed to two estrogenic alkylphenols for 60 days post-hatch had

403 concentration-dependent increases in hepatic VTG in both sexes (Seki et al., 2003).

404 Whole body VTG increased in fathead minnow exposed to $\mathrm{EE}_{2}$ for 142 days post-hatch

405 (Länge et al., 2001). Adult female mummichog had elevated plasma VTG at 100ng/L

$406 \mathrm{EE}_{2}$ in a 15-day exposure (MacLatchy et al., 2003), indicating consistent effects through 
407 different life stages in this species. While liver sizes in fish generally increase during

408 vitellogenesis (Kleinkauf et al., 2004), there was no correlation between LSI and liver

409 VTG in this study (data not shown).

410 At 52 weeks post-hatch, males exposed to $100 \mathrm{ng} / \mathrm{L} \mathrm{EE}_{2}$ had significantly lower

411 GSI than all other treatments and at week 61, males exposed to $100 \mathrm{ng} / \mathrm{L} \mathrm{EE}_{2}$ had GSIs

412 less than $60 \%$ of each of the other treatments. Male GSI decreased between week 52 and

413 week 61 in $0,0.1,1$ and $10 \mathrm{ng} / \mathrm{L} \mathrm{EE}_{2}$ treatments. Few males showed the brilliant yellow

414 of sexual maturity and it is possible that male GSI was decreasing due to the annual

415 reproductive cycle (week 61 was 26 August 2004). GSI in mummichog decreases as the

416 breeding season ends (Cochran, 1987). Male fish exposed to $100 \mathrm{ng} / \mathrm{L} \mathrm{EE}_{2}$ did not

417 demonstrate the reduction in GSI between weeks 52 and 61 observed in the other

418 treatments. Male zebrafish exposed for 24 days at 10 and $25 \mathrm{ng} / \mathrm{L} \mathrm{EE}_{2}$ showed reductions

419 in GSI, due to a predominance of immature sperm (Van den Belt et al., 2002). No

420 differences among treatments were found within each male gonadal maturation stage.

421 However, the high variability, especially in the $100 \mathrm{ng} / \mathrm{L}$ treatments, where only five male

422 fish had enough gonadal tissue to embed and section for analysis, may be masking an 423 effect.

424 There was no difference in GSI among treatments in female fish at 52 (June) or

42561 (August) weeks post-hatch. However, female GSI decreased between week 52 and

426 week 61 in fish exposed to $0,0.1$, and $1 \mathrm{ng} / \mathrm{L} \mathrm{EE}_{2}$, and did not change in female fish

427 exposed to 10 and $100 \mathrm{ng} / \mathrm{L} \mathrm{EE}_{2}$. These changes in GSI, and the increased proportion of

428 vitellogenic oocytes in female fish exposed to 1,10 and $100 \mathrm{ng} / \mathrm{L} \mathrm{EE}_{2}$, indicate that higher

429 levels of $\mathrm{EE}_{2}$ may cause differences in gonadal development during the spawning season. 
430 In the parental generation, there was also indication that $\mathrm{EE}_{2}$ exposure could cause

431 disruption to reproductive cycles in female mummichog. Adult females exposed to

432 higher concentrations of $\mathrm{EE}_{2}(1-100 \mathrm{ng} / \mathrm{L})$ had altered gonadal steroid production and

433 completed the spawning cycle earlier than fish exposed to 0 and $0.1 \mathrm{ng} / \mathrm{L} \mathrm{EE}_{2}$ (Peters et

434 al., 2007).

435 Sex ratios based upon secondary sexual characteristics, visual examination of the

436 gonads and histological analysis demonstrated skewed sex ratios at 100ng/L. Early life

437 exposure of mummichog to $\mathrm{EE}_{2}$ weakly skewed the sex ratio towards females, even when

438 raised following 60 days of post-hatch $\mathrm{EE}_{2}$ exposure in clean water (Boudreau et al.,

439 2004). Medaka eggs injected with $\mathrm{EE}_{2}$ have shown sex reversal of genetic males upon

440 growout (Papoulias et al., 1999) while medaka exposed to $\mathrm{EE}_{2}$ from two days post-hatch

441 had gonadal intersex at 2ng/L (Balch et al., 2004). Fathead minnow have been

442 completely feminized in lifecycle exposures to 4ng/L EE 2 (Länge et al., 2001) and

443 3.2ng/L (Parrott and Wood, 2002). Mummichog sex ratios appear to be affected at

444 higher exposure concentrations $\left(>10 \mathrm{ng} / \mathrm{L} \mathrm{EE}_{2}\right)$ than other species $\left(<5 \mathrm{ng} / \mathrm{L} \mathrm{EE}_{2}\right)$. Gonadal

445 sex change in fish can be induced by exposure to estrogens during windows of sensitivity

446 related to gonadal differentiation and development (Nakamura et al. 1998). The fathead

447 minnow has a period of enhanced sensitivity to $\mathrm{EE}_{2}$ between 10 and 15 days post-hatch,

448 when male fish are more likely to develop female characteristics (Van Aerle et al., 2002)

449 and 6-day exposures with medaka have demonstrated that exposure while an embryo,

450 newly hatched fry or 1 week post-hatch are sufficient to alter sex ratios and/or develop

451 intersex gonads at sexual maturity (Koger et al., 2000). In mummichog, the window of 
452 sensitivity to exogenous steroids during differentiation has not been precisely identified

453 but most likely occurs from 2-4 weeks after hatching (Urushitani et al., 2002).

$454 \quad \mathrm{EE}_{2}$ is typically found in low concentrations (0.1-10ng/L with amounts as high as

455 42ng/L in some cases) in Canadian sewage effluents (Desbrow et al., 1998; Ternes et al.,

456 1999). In the low range of environmentally-relevant concentrations, exposure to $\mathrm{EE}_{2}$

457 during different life stages results in minimal, if any, adverse effects on reproductive

458 endpoints (this study; MacLatchy et al., 2003; Boudreau et al., 2004). However,

459 exposure at the high end of the range ( $30 \%$ of nominal $100 \mathrm{ng} / \mathrm{L} \mathrm{EE_{2 }}$ exposure) negatively

460 affected larval and juvenile endpoints, including hatch success, liver VTG, male GSI, sex

461 ratios and female gonadal development in mummichog. Because these effects occurred

462 at the high range ( $>10 \mathrm{ng} / \mathrm{L}$ actual exposure), long-term full lifecycle exposures in

463 mummichog do not appear to offer advantages from a testing and sensitivity perspective

464 over the shorter-term adult reproductive test (e.g., Peters et al., 2007).

465 More studies are required to determine the relative sensitivities of different fish

466 species, including those typically classified as "model" species. In the present study, the

$467100 \mathrm{ng} / \mathrm{L}$ exposure averaged approximately $30 \%$ (30ng/L) over the course of a $24-\mathrm{h}$ day;

468 all other exposures were $\leq 10 \mathrm{ng} / \mathrm{L}$ nominal and therefore significantly less in actuality.

469 This makes comparison to other studies that had exposure concentrations $<10 \mathrm{ng} / \mathrm{L}$ or

$470>10 \mathrm{ng} / \mathrm{L}$ possible. Fathead minnow have failed development of secondary sex

471 characteristics, altered mating behaviour, intersex and induced VTG in males at 1-5 ng/L

$472 \mathrm{EE}_{2}$ (Länge et al., 2001; Lattier et al., 2002; Parrott and Blunt, 2005); Japanese medaka

473 display intersex and reduced copulations at 2-10ng/L EE 2 (Balch et al., 2004); and

474 zebrafish have reduced spawning, fertilization, intersex and GSI at 5-10ng/L EE 2 (Van 
475 den Belt et al., 2001; Van den Belt et al., 2002; Nash et al., 2004). In contrast to

476 freshwater species, in which effects are observed at concentrations $\leq 10 \mathrm{ng} / \mathrm{L} \mathrm{EE}_{2}$,

477 sheepshead minnow have reduced reproductive success at $\mathrm{EE}_{2}$ between 20 and 200ng/L

478 (Zillioux et al., 2001) while mummichog have altered steroid synthesis, VTG induction,

479 reproductive success and sex differentiation at $>10 \mathrm{ng} / \mathrm{L} \mathrm{EE}_{2}$ (MacLatchy et al., 2003;

480 Peters et al., 2007; this study). Clearly, all of these species show significant effects from

481 estrogen exposure during lifecycle exposure. Estuarine species, however, may have a

482 different level of sensitivity, and/or their uptake may be altered (e.g., differences in gill

483 vs. gut uptake), and/or the fate of contaminants may be different in saltwater than

484 freshwater systems. Clearly, further investigation is required to determine the roles of

485 physiology and physical environment on biological effects of EDSs in estuarine species

486 before determining whether zebrafish or other freshwater species with shorter life cycles

487 have significant test advantages and can be used as surrogate test species for regulating

488 EDS exposures in saltwater environments.

489 In mummichog, population-level adaptation to bio-accumulative, persistent

490 contaminants such as halogenated aryl hydrocarbons has been observed in field and lab

491 studies (Nacci et al., 1999); the mechanism for such adaptation is associated with a

492 consistent lack of inducibility of genes that are normally inducible by aryl hydrocarbon

493 receptor agonists (Meyer et al., 2003). In the highly-polluted New Bedford Harbor

494 (Massachusetts, USA), reproductively-active males and females demonstrate different

495 physiological (e.g., lower estrogen and androgen levels) and molecular (e.g., higher brain

496 P450 aromatase B expression) states compared to reference-site fish. Despite these

497 effects, gonadal sex differentiation, reproduction and embryonic/larval development are 
498 within normal ranges even following multi-generational exposure to estrogenic

499 contaminants (Greytak et al., 2003). Further studies are required to complete the picture

500 linking physiological/molecular effects and population-level effects in fish exposed to

501 EDSs; better understanding of these links may help explain differences in species

502 sensitivities.

503 In conclusion, this is the first lifecycle exposure of mummichog to $\mathrm{EE}_{2}$ and

504 demonstrates that continued development of bioassay protocols in this cyclical, lunar

505 spawner of the east coast of North America can provide useful models for the study of

506 EDSs. The concentration levels at which effects occurred in the offspring were greater

507 than have been shown for freshwater species and at the same approximate level shown to

508 have effects in the mummichog adult reproductive test $(>10 \mathrm{ng} / \mathrm{L})$. Of most concern in

509 this study are endpoints with the potential to affect the population structure. Chronic

510 exposure of successive generations of mummichog to $\mathrm{EE}_{2}$ resulted in reduced spawning

511 (Peters et al., 2007), fertilization and hatching, as well as altered sex ratios and gonadal

512 development. This implies fewer fish being added to the population with each successive

513 year; coupled with altered GSIs in adult and juvenile males, problems could compound

514 with time. Severe effects of $\mathrm{EE}_{2}$ on a population of fathead minnow have recently been

515 demonstrated in a whole-lake experiment (Kidd et al. 2007), demonstrating cause for

516 concern of environmentally-relevant $\mathrm{EE}_{2}$ concentrations on fish populations.

\section{Acknowledgements}


520 This study was funded by a Discovery Grant to DLM from the Natural Sciences and

521 Engineering Research Council of Canada as well as a Networks of Centres of Excellence:

522 Canadian Water Network grant to DLM (PI: K. Munkittrick, UNB Saint John). At UNB

523 Saint John, the following technicians and students are thanked for their assistance with

524 the exposure bioassays and laboratory work: J. Adams, A. Bennett, M. Beyea, C. Blanar,

525 K. Gormley, J. Ings, L. Peters, R. Sharpe, K. Shaughnessy, G. Vallieres, and L.Vallis.

\section{References}

528 Anadu, D.I., Scott, G.I., Fulton, M.H., 1999. Toxicity of DDT to the different life stages

529 of the mummichog Fundulus heteroclitus (Wabum). Bulletin of Environmental

530 Contamination and Toxicology 63, 181-187.

531

532 Andersen, L., Holbech, H., Gessbo, A., Norrgren, L., Petersen, G.I., 2003. Effects of

533 exposure to $17 \alpha$-ethinylestradiol during early development on sexual differentiation and

534 induction of vitellogenin in zebrafish (Danio rerio). Comparative Biochemistry and

535 Physiology C 134, 365-374.

536

537 Andersen, J.T., 1988. A review of size dependent survival during pre-recruit stages of

538 fishes in relation to recruitment. Journal of Northwest Atlantic Fishery Science 8, 55-66.

540 Ankley, G.T., Jensen, K.M., Kahl, M.D., Korte, J.J., Makynen, E.A., 2001. Description

541 and evaluation of a short-term reproduction test with the fathead minnow (Pimephales

542 promelas). Environmental Toxicology and Chemistry 20, 1276-1290. 
544 Armstrong, P.B., Child, J.S., 1965. Stages in the normal development of Fundulus

545 heteroclitus. Biological Bulletin 128, 143-168.

547 Balch, G.C., MacKenzie, C.A., Metcalfe, C.D., 2004. Alterations to gonadal

548 development and reproductive success in Japanese medaka (Oryzias latipes) exposed to

549 17 $\alpha$-ethinylestradiol. Environmental Toxicology and Chemistry 23, 782-791.

551 Blazer, V.S., 2002. Histopathological assessment of gonadal tissue in wild fishes. Fish

552 Physiology and Biochemistry 26, 85-101.

554 Bosker, T., Munkittrick, K., MacLatchy, D., 2009. Challenges in current adult fish

555 laboratory reproductive tests: suggestions for refinement using a mummichog (Fundulus

556 heteroclitus) case study. Environmental Toxicology and Chemistry In press.

558 Boudreau, M., Courtenay, S.C., MacLatchy, D.L., Bérubé, C.H., Hewitt, L.M., and Van

559 Der Kraak, G.J., 2005. Morphological abnormalities during early-life development of the

560 estuarine mummichog, Fundulus heteroclitus, as an indicator of androgenic and anti-

561 androgenic endocrine disruption. Aquatic Toxicology 71, 357-369.

563 Boudreau, M., Courtenay, S.C., MacLatchy, D.L., Bérubé, C.H., Parrott, J.L., Van der

564 Kraak, G.J., 2004. Utility of morphological abnormalities during early-life development

565 of the estuarine mummichog, Fundulus heteroclitus, as an indicator of estrogenic and 
566 antiestrogenic endocrine disruption. Environmental Toxicology and Chemistry 23, 415-

567425.

568

569

570 Cargnelli, L.M., Gross, M.R., 1996. The temporal dimension in fish recruitment: birth

571 date, body size, and size-dependent survival in a sunfish (bluegill: Lepomis macrochirus).

572 Canadian Journal of Fisheries and Aquatics Sciences 53, 360-367.

574 Cochran, R.C., 1987. Serum androgens during the annual reproductive cycle of the male 575 mummichog, Fundulus heteroclitus. General and Comparative Endocrinology 65, 141576148.

578 Denslow, N.D., Chow, M.C., Kroll, K.J., Green, L., 1999. Vitellogenin as a biomarker of 579 exposure for estrogen or estrogen mimics. Ecotoxicology 8, 385-398.

581 Desbrow, C., Routledge, E.J., Brighty, G.C., Sumpter, J.P., Waldock, M., 1998.

582 Identification of estrogenic chemicals in STW effluent. 1. Chemical fractionation and in 583 vitro biological screening. Environ. Sci. Technol. 32, 1549-1558.

585 Dubé, M., MacLatchy, D., Culp, J., Gillis, G., Parker, R., Courtenay, S., Gilman, C., 586 2002. Utility of mobile, field-based artificial streams for assessing effects of pulp mill 587 effluents on fish in the Canadian environmental effects monitoring (EEM) program. 588 Journal of Aquatic Ecosystem Stress and Recovery 9, 85-102. 
590 Environment Canada. 2005. Pulp and Paper EEM Technical Guidance Document.

591 Ottawa, Ontario, Canada.

592 http://www.ec.gc.ca/EEm/Englsih/PulpPaper/Guidance/default.cfm

594 Folmar, L.C., Gardner, G.R., Schreibman, M.P., Magliulo-Cepriano, L., Mill, L.J.,

595 Zaroogian, G., Gutjahr-Gobell, R., Haebler, R., Horowitz, D.B., Denslow, N.D., 2001.

596 Vitellogenin-induced pathology in male summer flounder (Paralichthys dentatus).

597 Aquatic Toxicology 51:431-454.

598

599 Folmar, L.C., Hemmer, M., Hemmer, R., Bowman, C., Kroll, K., Denslow, N.D., 2000.

600 Comparative estrogenicity of estradiol, ethynyl estradiol and diethylstilbestrol in an in

601 vivo, male sheepshead minnow (Cyprinodon variegatus), vitellogenin bioassay. Aquatic

602 Toxicology 49, 77-88.

603

604 Greytak, S.R., Champlin, D., Callard, G., 2005. Isolation and characterization of two

605 cytochrome P450 aromatase forms in killifish (Fundulus heteroclitus): Differential

606 expression in fish from polluted and unpolluted environments. Aquatic Toxicology 71,

$607 \quad 371-389$.

608

609 Hemmer, M.J., Cripe, G.M., Hemmer, B.L., Goodman, L.R., Salinas, K.A., Furnie, J.W.,

610 Walker, C.C., 2008. Comparison of estrogen-responsive plasma protein biomarkers and 
611 reproductive endopoints in sheepshead minnows exposed to $17 \beta$-trenbolone. Aquatic

612 Toxicology $88,128-136$.

613

614 Hewitt, M., Kovacs, T., Dubé, M., MacLatchy, D., Martel, P., McMaster, M., Paice, M.,

615 Parrott, J., van den Heuvel, M., Van Der Kraak, G., 2008. Altered reproduction in fish

616 exposed to pulp and paper mill effluents: A review of the roles of individual compounds

617 and mill operating conditions. Environmental Toxicology and Chemistry 3, 682-697. 618

619 Jobling, S., Tyler, C., 2003. Endocrine disruption in wild freshwater fish. Pure and 620 Applied Chemistry 75, 2219-2234.

621

622 Kelly, S.A., Di Giulio, R.T., 2000. Developmental toxicity of estrogenic alkylphenols in

623 killifish (Fundulus heteroclitus). Environmental Toxicology and Chemistry 19, 2564-

6242570.

625

626 Kidd, K.A., Blanchfield, P.J., Mills, H., Palace, V.P., Evans, R.E., Lazorchak, J.M.,

627 Flick, R., 2007. Collapse of a fish population following exposure to a synthetic estrogen.

628 Proceedings of the National Academy of Sciences 104, 8897-8901.

629

630 Kleinkauf, A., Connor., L., Swarbreck, D., Levene, C., Walker, P., Johnson, P.J., Leah,

631 R.T., 2004. General condition biomarkers in relation to contaminant burden in European

632 flounder (Platichthys flesus). Ecotoxicology and Environmental Safety 58, 335-355.

633 
634 Koger, C.S., Teh, S.J., Hinton, D.E., 2000. Determining the sensitive developmental

635 stages of intersex induction in medaka (Oryzias latipes) exposed to $17 \beta$-estradiol or

636 testosterone. Marine Environmental Research 50, 201-206.

637

638 Länge, R., Hutchinson, T.H., Croudace, C.P., Siegmund, F., Schweinfurth, H., Hampe,

639 P., Panter, G.H., Sumpter, J.P., 2001. Effects of the synthetic estrogen $17 \alpha-$

640 ethinylestradiol on the life-cycle of the fathead minnow (Pimephales promelas).

641 Environmental Toxicology and Chemistry 20, 1216-1227.

642

643 Lattier, D.L., Reddy, T.V., Gordon, D.A., Lazorchak, J.M., Smith, M.E., Williams, D.E.,

644 Wiechman, B., Flick, R.W., Miracle, A.L., Toth, G.P., 2002. 17 $\alpha$-ethynylestradiol-

645 induced vitellogenin gene transcription quantified in livers of adult males, larvae, and

646 gills of fathead minnows (Pimephales promelas). Environmental Toxicology and

647 Chemistry 21, 2385-2393.

648

649 LeBlanc, J., Couillard, C.M., Brêthes J.-C.F., 1997. Modifications of the reproductive

650 period in mummichog (Fundulus heteroclitus) living downstream from a bleached kraft

651 pulp mill in the Miramichi estuary, New Brunswick, Canada. Canadian Journal of

652 Fisheries and Aquatics Sciences 54, 2564-2573.

653

654 Lehtinen, K.-J., Mattsson, K., Tana, J., Engström, C., Lerche, O., Hemming, J., 1999.

655 Effects of wood-related sterols on the reproduction, egg survival, and offspring of brown

656 trout (Salmo trutta lacustris L.). Ecotoxicology and Environmental Safety 42, 40-49. 
658 MacLatchy, D.L., Courtenay, S.C., Rice, C.D., Van der Kraak, G.J., 2003. Development

659 of a short-term reproductive endocrine bioassay using steroid hormone and vitellogenin

660 end points in the estuarine mummichog (Fundulus heteroclitus). Environmental

661 Toxicology and Chemistry 22, 996-1008.

662

663 MacLatchy, D.L., Gormley, K.L., Ibey, R.E.M., Sharpe, R.L., Shaughnessy, K.S.,

664 Courtenay S.C., Dubé, M.G., Van der Kraak, G.J., 2005. A short-term mummichog

665 (Fundulus heteroclitus) bioassay to assess endocrine response to hormone-active

666 compounds and mixtures, In: Ostrander, G.K. (Ed.) Techniques in Aquatic Toxicology,

667 Vol 2. CRC Press, New York, pp. 55-91.

668

669 Metcalfe, C.D., Metcalfe, T.L., Kiparissis, Y., Koenig, B.G., Khan, C., Hughes, R.J.,

670 Crolet, T.R., March R.E., Potter, T., 2001. Estrogenic potency of chemicals detected in

671 sewage treatment plant effluents as determined by in vivo assays with Japanese medaka

672 (Oryzias latipes). Environmental Toxicology and Chemistry 20, 297-308.

673

674 Meyer, J.N., Wassenberg, D.M., Karchner, S.I., Hahn, M.E., Di Giulio, R.T., 2003.

675 Expression and inducibility of aryl hydrocarbon receptor pathway genes in wild-caught

676 killifish (Fundulus heteroclitus) with different contaminant-exposure histories.

677 Environmental Toxicology and Chemistry 22, 2337-2343.

678 
679 Miller, D.H., Jensen, K.M., Villenuve, D.L., Kahl, M.D., Makynen, E.A., Durhan, E.J., 680 Ankley, G.T. 2007. Linkage of biochemical responses to population-level effects: a case 681 study with vitellogenin in the fathead minnow (Pimiphales promelas). Environmental 682 Toxicology and Chemistry 26, 521-527.

683

684 Nacci, D., Coiro, L., Champlin, D., Jayaraman, S., McKinney, R., Gleason, T.R., Munns, 685 W.R., Specker, J.L., Cooper, K.R., 1999. Adaptations of wild populations of the estuarine 686 fish Fundulus heteroclitus to persistent environmental contaminants. Marine Biology $687 \quad 134,9-17$.

688

689 Nakamura, M., Kobayashi, T., Chang, X.-T., Nagahama, Y., 1998. Gonadal sex

690 differentiation in teleost fish. Journal of Experimental Zoology. 281, 362-372.

691

692 Nash, J.P., Kime, D.E., Van der Ven, L.T.M., Wester, P.W., Brion, F., Maack, G.,

693 Stahlschmidt-Allner, P., Tyler, C.R., 2004. Lont-term exposure to environmental

694 concentrations of the pharmaceutical ethynylestradiol causes reproductive failure in fish.

695 Environmental Health Perspectives 112, 1725-1733.

696

697 Oberdörster E., Cheek A.O., 2000. Gender benders at the beach: endocrine disruption in 698 marine and estuarine organisms. Environmental Toxicology and Chemistry 20, 23-36. 699 
700 Olsson, P.E., Westerlund, L., Teh, S.J., Billsson, K., Berg A.H., Tysklind, M., Nilsson, J.,

701 Eriksson, L.-O., Hinton D.E., 1999. Effects of maternal exposure to estrogen and PCB on

702 different life stages of zebrafish, Danio rerio. Ambio 28, 100-106.

703

704 Organization of Economic Cooperation and Development, 1999. Final report from the

705 OECD expert consultation meeting, London, UK, October 28-29, 1998. Report 9906.

706 Environmental Health and Safety Division, Paris, France.

707

708 Panter, G.H., Hutchinson, T.H., Länge, R., Lye, C.M., Sumpter, J.P., Zerulla, M., Tyler,

709 C.R., 2002. Utility of a juvenile fathead minnow screening assay for detecting (anti-)

710 estrogenic substances. Environmental Toxicology and Chemistry 21, 319-326.

711

712 Papoulias, D.M., Noltie, D.B., Tillitt, D.E., 1999. An in vivo model fish system to test

713 chemical effects on sexual differentiation and development: exposure to ethinyl estradiol.

714 Aquatic Toxicology 48, 37-50.

715

716 Parrott, J.L., Wood, C.S., 2002. Fathead minnow lifecycle tests for detection of

717 endocrine-disrupting substances in effluents. Water Quality Research Journal of Canada

$718 \quad 37,651-667$.

719

720 Parrott, J.L., Blunt, B.R., 2005. Life-cycle exposure of fathead minnows (Pimephales

721 promelas) to an ethinylestradiol concentration below $1 \mathrm{ng} / \mathrm{L}$ reduces egg fertilization

722 success and demasculinizes males. Environmental Toxicology 20, 131-141. 
724 Patyna, P.J., Davi, R.A., Parkerton, T.F., Brown, R.P., Cooper, K.R., 1999. A proposed

725 multigenerational protocol for Japanese medaka (Oryzias latipes) to evaluate effects of

726 endocrine disruptors. Science of the Total Environment 233, 211-220.

728 Peters, R.E.M., Courtenay, S.C., Cagampan, S., Hewitt, M.L., MacLatchy, D.L., 2007.

729 Effects on reproductive potential and endocrine status in the mummichog (Fundulus

730 heteroclitus) after exposure to $17 \alpha$-ethynylestradiol in a short-term reproductive bioassay.

731 Aquatic Toxicology 85, 154-166.

732

733 Seki, M., Yokota, H., Matsubara, H., Maeda, M., Tadokoro, H., Kobayashi, K., 2003.

734 Fish full life-cycle testing for the weak estrogen 4-tert-pentylphenol on medaka (Oryzias

735 latipes). Environmental Toxicology and Chemistry 22, 1487-1496. 
736 Seki, M., Yokota, H., Matsubara, H., Maeda, M., Tadokoro, H., Kobayashi, K., 2004.

737 Fish full life-cycle testing for androgen methyltestosterone on medaka (Oryzias latipes).

738 Environmental Toxicology and Chemistry 23: 774-781.

740 Sharpe R.L., MacLatchy D.L., Courtenay S.C., Van Der Kraak, G.J., 2004. Effects of a

741 model androgen (methyl testosterone) and a model anti-androgen (cyproterone acetate)

742 on reproductive endocrine endpoints in a short-term adult mummichog (Fundulus

743 heteroclitus) bioassay. Aquatic Toxicology 67, 203-215.

745 Skinner, M.A., Courtenay, S.C., Parker, W.R., Curry, R.A. 2005. Site fidelity of

746 mummichogs (Fundulus heteroclitus) in an Atlantic Canadian estuary. Water Quality

747 Research Journal of Canada 40, 288-298.

749 Ternes, T.A., Stumpf, M., Mueller, J., Haberer, K., Wilken, R.-D., Servos, M., 1999.

750 Behavior and occurrence of estrogens in municipal sewage treatment plants - I.

751 Investigations in Germany, Canada, and Brazil. Science of the Total Environment 225,

$752 \quad 81-90$

753

754 Urushitani, H., Shimizu, A., Katsu, Y., Iguchi, T., 2002. Early estrogen exposure induces

755 abnormal development of Fundulus heteroclitus. Journal of Experimental Zoology 293, $756 \quad 693-702$. 
758 Van Aerle, R., Pounds, N., Hutchinson, T.H., Maddix, S., Tyler, C.R., 2002. Window of

759 sensitivity for the estrogenic effects of ethinylestradiol in early life stages of fathead

760 minnow (Pimephales promelas). Ecotoxicology 11, 423-434.

761

762 Van den Belt, K., Verheyen, R., Witters, H., 2001. Reproductive effects of

763 ethynylestradiol and 4t-octylphenol on the zebrafish (Danio rerio). Archives of

764 Environmental Contamination and Toxicology 41, 458-467.

766 Van den Belt, K., Wester, P.W., Van der Ven, L.T.M., Vergeyen, R., Witters, H., 2002.

767 Effects of ethynylestradiol on the reproductive physiology in zebrafish (Danio rerio):

768 Time dependency and reversibility. Environmental Toxicology and Chemistry 21, 767-

769775.

770

771 Versonnen, B.J., Roose, P., Monteyne, E.M., Janssen, C.R., 2004. Estrogenic and toxic

772 effects of methoxychlor on zebrafish (Danio rerio). Environmental Toxicology and

773 Chemistry 23, 2194-2201.

774

775 Zar, J.H., 1999. Biostatistical Analysis. Prentice Hall, Upper Saddle River, NJ, USA 776

777 Zillioux, E.J., Johnson, I.C., Kiparissis, Y., Metcalfe, C.D., Wheat, J.V., Ward, S.G., Liu,

778 H., 2001. The sheepshead minnow as an in vivo model for endocrine disruption in

779 marine teleosts: a partial life-cycle test with 17 $\alpha$-ethynylestradiol. Environmental

780 Toxicology and Chemistry 20, 1968-1978. 


\section{$781 \quad$ Figures}

782

783 Figure 1. (A) Mean time to hatch of mummichog eggs exposed to $0,0.1,1,10$, or

784 100ng/L 17 $\alpha$-ethynylestradiol $\left(\mathrm{EE}_{2}\right)$. (B) Mean hatch success of mummichog eggs

785 exposed to $0,0.1,1,10$, or $100 \mathrm{ng} / \mathrm{L} \mathrm{EE}_{2}$. (C) Mean length at hatch of mummichog larvae

786 exposed to $0,0.1,1,10$, or $100 \mathrm{ng} / \mathrm{L} \mathrm{EE}_{2}$. Bars represent means $\pm \mathrm{SE}$. Means showing

787 different letters are significantly different $(\mathrm{p}<0.05) . \mathrm{n}=39-51$ Petri dishes per treatment.

789 Figure 2. Mean survival of mummichog exposed to $0,0.1,1,10$, or $100 \mathrm{ng} / \mathrm{L} 17 \alpha-$

790 ethynylestradiol from hatch to 61 weeks post-hatch. $n=3-4$ tanks per treatment.

791

792 Figure 3. Mean prevalence of vertebral abnormalities in juvenile mummichog exposed to

$7930,0.1,1,10$, or $100 \mathrm{ng} / \mathrm{L} 17 \alpha$-ethynylestradiol at week 15 post-hatch. Bars represent

794 means \pm SE. Means showing different letters are significantly different $(p<0.05) . \quad n=3-4$

795 tanks per treatment. 
1 Table 1: Mean $( \pm 1 \mathrm{SE})$ weight, length, liver somatic index (LSI), gonadosomatic index

2 (GSI), and condition factor for juvenile male and female Fundulus heteroclitus exposed

3 to $17 \alpha$-ethynylestradiol $\left(\mathrm{EE}_{2}\right)$ from fertilization at 61 weeks after hatch. Different letters

4 identify significantly different treatments within variables $(\mathrm{p}<0.05)$.

\begin{tabular}{cccccccc}
\hline Sex & $\begin{array}{c}\text { Treatment } \\
(\mathrm{ng} / \mathrm{L})\end{array}$ & $\mathrm{n}$ & Weight (g) & Length (cm) & LSI (\%) & GSI (\%) & $\begin{array}{c}\text { Condition } \\
(\%)\end{array}$ \\
\hline & 0 & 26 & $0.85 \pm 0.06^{\mathrm{a}}$ & $3.76 \pm 0.08^{\mathrm{a}}$ & $2.35 \pm 0.16^{\mathrm{a}}$ & $0.86 \pm 0.12^{\mathrm{a}}$ & $1.57 \pm 0.07^{\mathrm{a}}$ \\
& 0.1 & 37 & $0.71 \pm 0.05^{\mathrm{a}}$ & $3.55 \pm 0.08^{\mathrm{a}}$ & $1.97 \pm 0.12^{\mathrm{a}}$ & $0.77 \pm 0.08^{\mathrm{a}}$ & $1.50 \pm 0.05^{\mathrm{a}}$ \\
Male & 1 & 51 & $0.85 \pm 0.05^{\mathrm{a}}$ & $3.70 \pm 0.07^{\mathrm{a}}$ & $1.98 \pm 0.13^{\mathrm{a}}$ & $0.78 \pm 0.07^{\mathrm{a}}$ & $1.60 \pm 0.04^{\mathrm{a}}$ \\
& 10 & 34 & $0.83 \pm 0.06^{\mathrm{a}}$ & $3.72 \pm 0.07^{\mathrm{a}}$ & $2.33 \pm 0.17^{\mathrm{a}}$ & $0.82 \pm 0.10^{\mathrm{a}}$ & $1.54 \pm 0.06^{\mathrm{a}}$ \\
& 100 & 12 & $0.65 \pm 0.07^{\mathrm{a}}$ & $3.53 \pm 0.15^{\mathrm{a}}$ & $2.27 \pm 0.35^{\mathrm{a}}$ & $0.45 \pm 0.13^{\mathrm{a}}$ & $1.46 \pm 0.10^{\mathrm{a}}$ \\
& $\mathrm{p}-$ value & & 0.155 & 0.497 & 0.242 & 0.395 & 0.418 \\
\hline \multirow{4}{*}{ Female } & 0 & 27 & $0.94 \pm 0.05^{\mathrm{ab}}$ & $3.91 \pm 0.08^{\mathrm{a}}$ & $2.45 \pm 0.19^{\mathrm{ab}}$ & $2.78 \pm 0.77^{\mathrm{a}}$ & $1.56 \pm 0.05^{\mathrm{ab}}$ \\
& 0.1 & 42 & $0.85 \pm 0.05^{\mathrm{a}}$ & $3.82 \pm 0.08^{\mathrm{a}}$ & $2.59 \pm 0.15^{\mathrm{ac}}$ & $1.78 \pm 0.09^{\mathrm{a}}$ & $1.49 \pm 0.07^{\mathrm{a}}$ \\
& 1 & 45 & $0.98 \pm 0.05^{\mathrm{ab}}$ & $3.93 \pm 0.08^{\mathrm{a}}$ & $2.05 \pm 0.14^{\mathrm{b}}$ & $2.07 \pm 0.19^{\mathrm{a}}$ & $1.58 \pm 0.04^{\mathrm{ab}}$ \\
& 10 & 38 & $0.91 \pm 0.06^{\mathrm{ab}}$ & $3.83 \pm 0.07^{\mathrm{a}}$ & $2.85 \pm 0.10^{\mathrm{a}}$ & $3.62 \pm 0.79^{\mathrm{a}}$ & $1.57 \pm 0.04^{\mathrm{ab}}$ \\
& 100 & 47 & $1.11 \pm 0.06^{\mathrm{b}}$ & $4.04 \pm 0.07^{\mathrm{a}}$ & $2.24 \pm 0.11^{\mathrm{bc}}$ & $3.56 \pm 0.81^{\mathrm{a}}$ & $1.65 \pm 0.06^{\mathrm{b}}$ \\
& $\mathrm{p}-\mathrm{value}$ & & 0.025 & 0.371 & $<0.001$ & 0.364 & 0.024 \\
\hline
\end{tabular}


1 Table 2. Proportion (mean $\pm 1 \mathrm{SE}$ ) of juvenile mummichog exhibiting female secondary sex

2 characteristics and/or female gonads at 52 weeks post-hatch after exposure to $0,0.1,1,10$ or

$3100 \mathrm{ng} / \mathrm{L} \mathrm{EE}_{2}$. Differing superscripts identify significantly different treatments $(\mathrm{p}<0.05) . \mathrm{n}=3-4$

4 tanks per treatment.

5

\begin{tabular}{lcccc}
\hline & & \multicolumn{2}{c}{ Mean \% + \pm SE } & \\
Treatment (ng/L) & N & Secondary Sex Characteristics & Gonadal Sex & Histological Sex \\
\hline 0 & 3 & $0.514 \pm 0.104^{\mathrm{a}}$ & $0.495 \pm 0.095^{\mathrm{a}}$ & $0.583 \pm 0.084^{\mathrm{a}}$ \\
0.1 & 4 & $0.462 \pm 0.078^{\mathrm{a}}$ & $0.480 \pm 0.045^{\mathrm{a}}$ & $0.430 \pm 0.043^{\mathrm{a}}$ \\
1 & 3 & $0.594 \pm 0.075^{\mathrm{a}}$ & $0.567 \pm 0.058^{\mathrm{a}}$ & $0.602 \square 0.033^{\mathrm{b}}$ \\
10 & 4 & $0.580 \pm 0.084^{\mathrm{a}}$ & $0.525 \pm 0.103^{\mathrm{a}}$ & $0.570 \square 0.076^{\mathrm{a}}$ \\
100 & 3 & $0.928 \pm 0.043^{\mathrm{b}}$ & $0.868 \pm 0.076^{\mathrm{b}}$ & $0.861 \square 0.071^{\mathrm{b}}$ \\
\hline
\end{tabular}

6 
Table 3. Developmental stages of gonadal tissue for female and male juvenile mummichog exposed to $0,0.1,1,10$ or $100 \mathrm{ng} / \mathrm{L} \mathrm{EE}_{2}$ at 52 weeks post-hatch. Proportion (mean $\pm 1 \mathrm{SE}$ ) of fish with vitellogenic gonads (females) and spermatogenic gonads (males) is shown. Differing superscripts identify significantly different treatments $(\mathrm{p}<0.05)$ within each gonadal stage. $n=2-4$ tanks per treatment.

\begin{tabular}{ccccc}
\hline & & Females & \multicolumn{2}{l}{ Males } \\
\hline Treatment (ng/L) & n & Vitellogenic & n & Spermatogenic \\
\hline 0 & 3 & $0.467 \pm 0.014^{\mathrm{a}}$ & 3 & $0.590 \pm 0.117^{\mathrm{a}}$ \\
0.1 & 4 & $0.519 \pm 0.024^{\mathrm{ab}}$ & 3 & $0.703 \pm 0.104^{\mathrm{a}}$ \\
1 & 3 & $0.526 \pm 0.040^{\mathrm{bc}}$ & 3 & $0.515 \pm 0.039^{\mathrm{a}}$ \\
10 & 4 & $0.565 \pm 0.008^{\mathrm{d}}$ & 4 & $0.431 \pm 0.067^{\mathrm{a}}$ \\
100 & 3 & $0.504 \pm 0.039^{\mathrm{bc}}$ & 2 & $0.195 \pm 0.195^{\mathrm{a}}$ \\
\hline
\end{tabular}


(A)

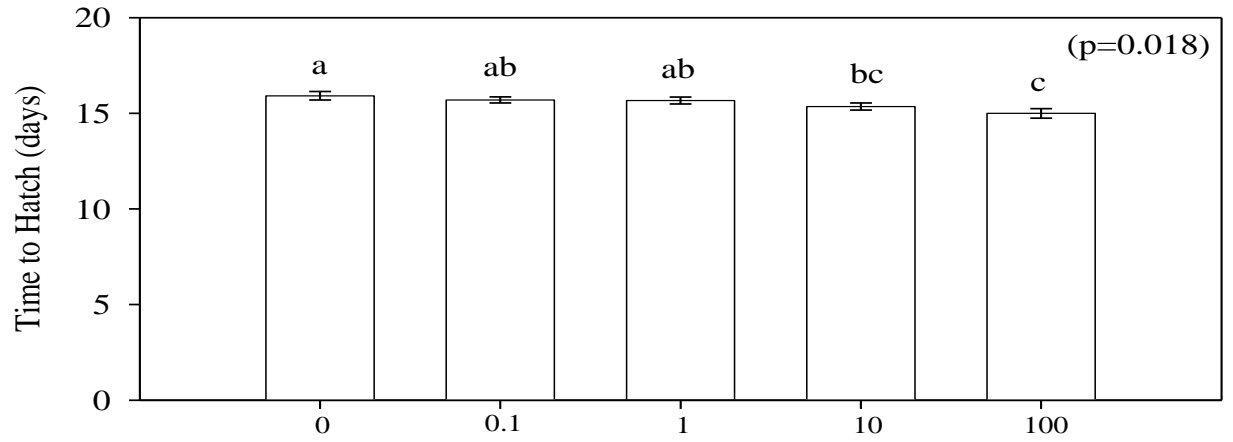

(B)

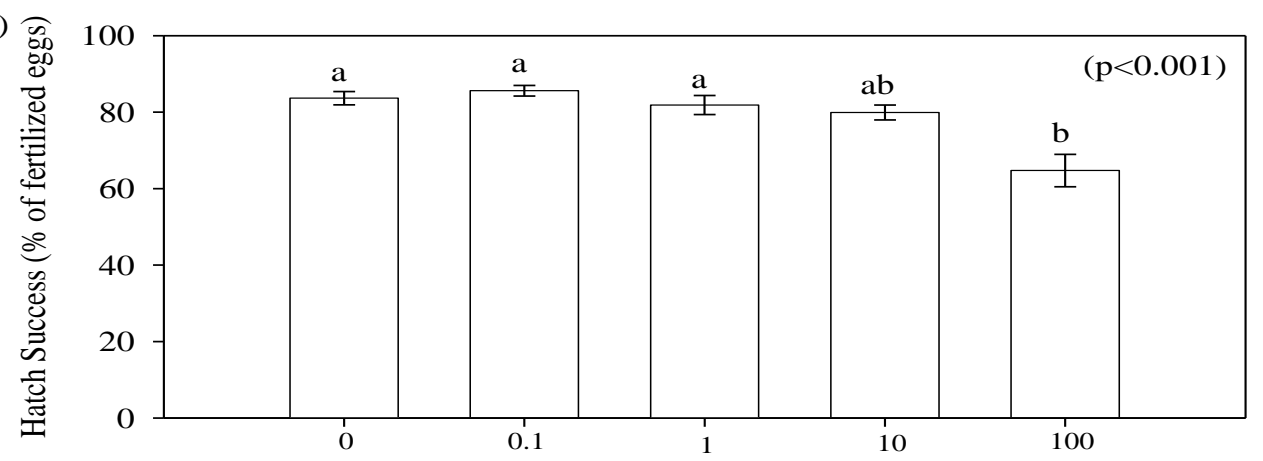

(C)

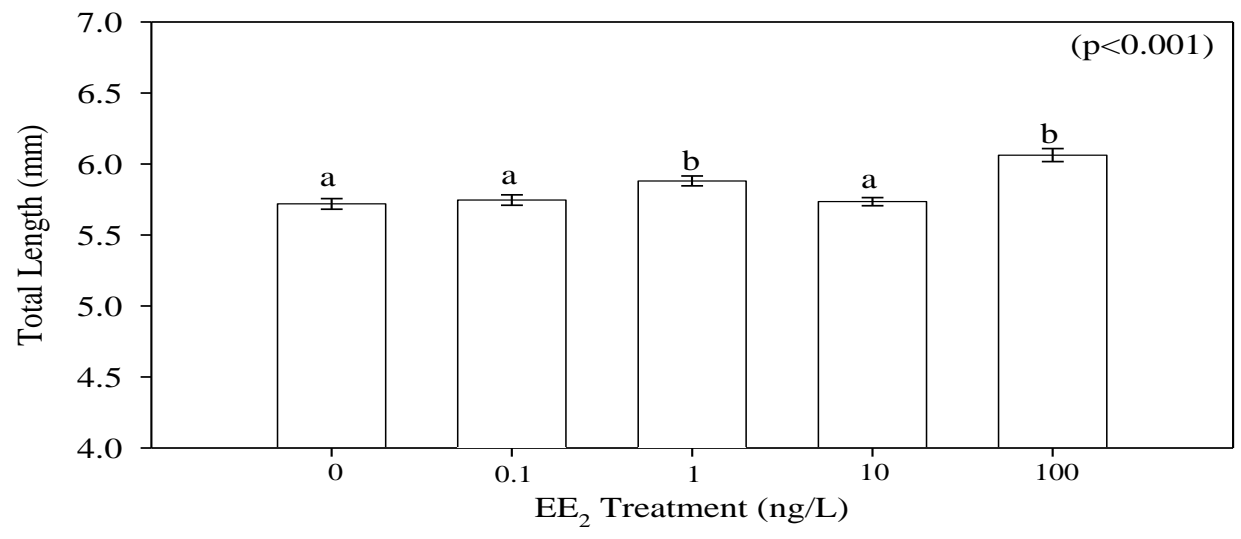

Figure 1 


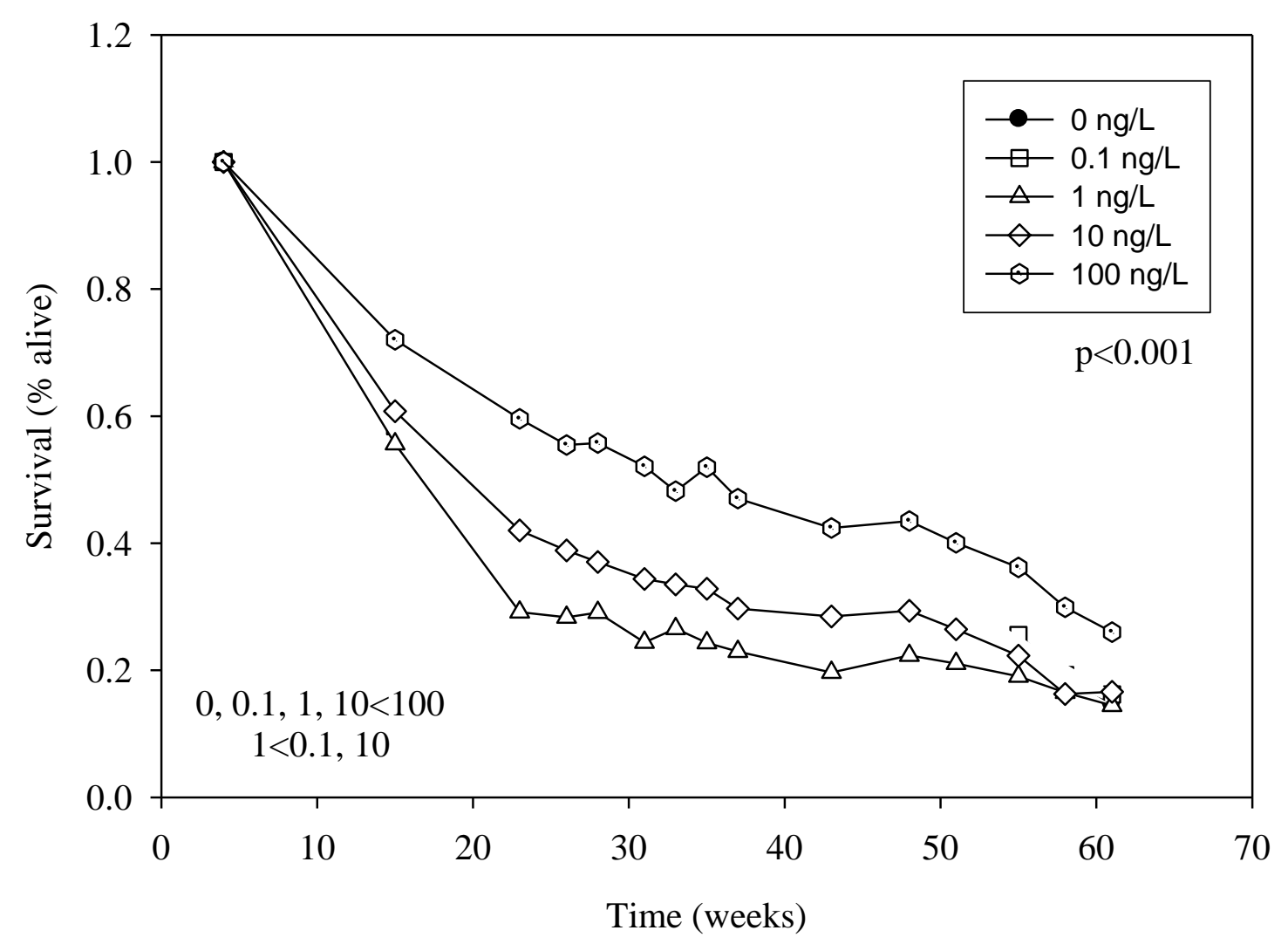

Figure 2 


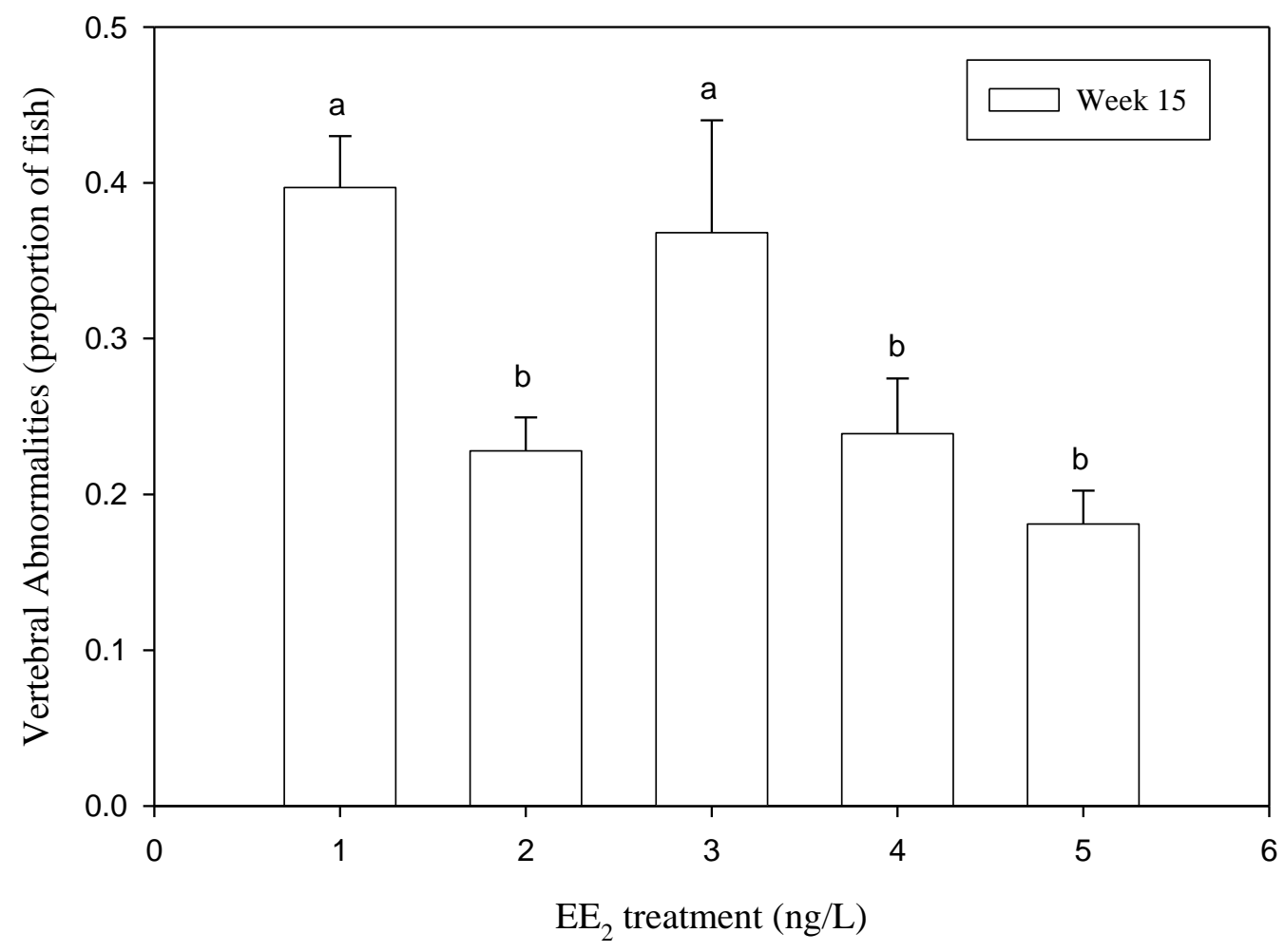

Figure 3 